\title{
Fluvial sediment transport and deposition following the 1991 eruption of Mount Pinatubo
}

\author{
Shannon K. Hayes ${ }^{\mathrm{a}, *}$, David R. Montgomery ${ }^{\mathrm{a}}$, Christopher G. Newhall ${ }^{\mathrm{b}}$ \\ ${ }^{a}$ Department of Geological Sciences, University of Washington, Seattle, WA 98195, USA \\ ${ }^{\mathrm{b}}$ U.S. Geological Survey, University of Washington, Seattle, WA 98195, USA
}

Received 24 January 2001; received in revised form 26 June 2001; accepted 28 September 2001

\begin{abstract}
The 1991 eruption of Mount Pinatubo generated extreme sediment yields from watersheds heavily impacted by pyroclastic flows. Bedload sampling in the Pasig-Potrero River, one of the most heavily impacted rivers, revealed negligible critical shear stress and very high transport rates that reflected an essentially unlimited sediment supply and the enhanced mobility of particles moving over a smooth, fine-grained bed. Dimensionless bedload transport rates in the Pasig-Potrero River differed substantially from those previously reported for rivers in temperate regions for the same dimensionless shear stress, but were similar to rates identified in rivers on other volcanoes and ephemeral streams in arid environments. The similarity between volcanically disturbed and arid rivers appears to arise from the lack of an armored bed surface due to very high relative sediment supply; in arid rivers, this is attributed to a flashy hydrograph, whereas volcanically disturbed rivers lack armoring due to sustained high rates of sediment delivery. This work suggests that the increases in sediment supply accompanying massive disturbance induce morphologic and hydrologic changes that temporarily enhance transport efficiency until the watershed recovers and sediment supply is reduced. (C) 2002 Elsevier Science B.V. All rights reserved.
\end{abstract}

Keywords: Bedload; Mount Pinatubo; Sediment transport; Volcano; Watershed disturbance

\section{Introduction}

Post-eruption sediment transport and deposition are major problems associated with explosive volcanic eruptions because these processes can cause widespread damage long after eruptions cease. Rivers impacted by volcanic eruptions have the highest recorded specific sediment yields (Fig. 1) due to increased runoff and erosion from hillslopes mantled

\footnotetext{
* Corresponding author. Present address: Forestry Sciences Laboratory, 3200 SW Jefferson Way, Corvallis, OR 97331, USA.

E-mail address: shannon.hayes@orst.edu (S.K. Hayes).
}

with fine-grained tephra, the destruction of stabilizing vegetation, and accompanying channel changes (Swanson et al., 1983; Collins and Dunne, 1986; Leavesley et al., 1989; Smith and Lowe, 1991; Pierson et al., 1992, 1996; Major et al., 1996). Although high erosion rates were previously described at several volcanoes (Segerstrom, 1950, 1960, 1966; Waldron, 1967; Ollier and Brown, 1971), detailed work following the 1980 eruption of Mount St. Helens increased recognition of the potential impacts of explosive eruptions on the hydrology of the surrounding landscape (Lisle et al., 1983; Swanson et al., 1983; Janda et al., 1984a,b; Collins and Dunne, 1986; Meyer and Martinson, 1989; Dinehart, 1998; Simon, 1999; Major et al., 


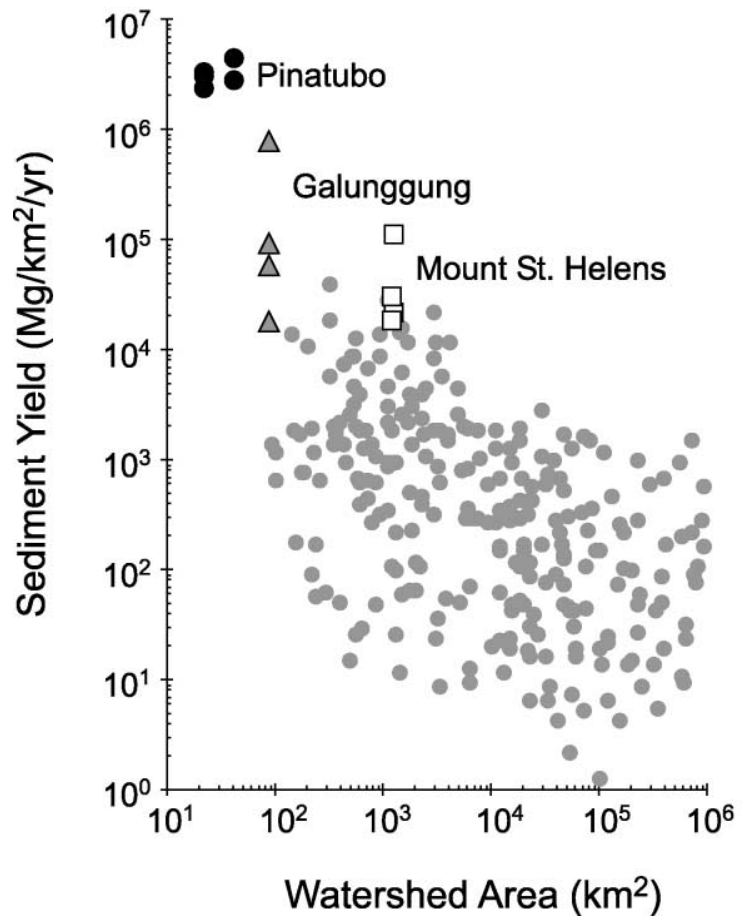

Fig. 1. Annual specific sediment yield versus watershed area of the Pasig-Potrero River draining Mount Pinatubo in 1991-1995 (PHIVOLCS, personal communication, 1998), the Toutle River draining Mount St. Helens, 1980-1984 (Dinehart, 1998), and the S. Cikunir River draining Galunggung volcano in Indonesia, 19821985 (Hirao and Yoshida, 1989), indicating significantly higher sediment yields in the first 4 years following explosive volcanic eruptions than in 280 rivers not impacted by volcanic eruptions (Milliman and Syvitski, 1992). Values plotted for Pinatubo and Galunggung were calculated from annual accumulated deposit volumes converted using average bulk deposit densities of $1.3 \mathrm{~g} /$ $\mathrm{cm}^{3}$, and underrepresent the total sediment yields since they are based solely on terrestrial overbank deposits.

2000). Since then, studies at Galunggung volcano in Indonesia (Hamidi, 1989; Hirao and Yoshida, 1989); Usu, Unzen, and Sakurajima in Japan (Watanabe and Ikeya, 1981; Kadomura et al., 1983; Shimokawa and Taniguchi, 1983; Chinen and Kadomura, 1986; Mizuyama and Kobashi, 1996); Ruapehu volcano in New Zealand (Cronin et al., 1999; Hodgson and Manville, 1999); Parícutin in Mexico (Inbar et al., 1994); and Mayon volcano and Mount Pinatubo in the Philippines have addressed the hydrologic response following explosive volcanic eruptions (Rodolfo, 1989; Rodolfo and Arguden, 1991; Pierson et al., 1992, 1996; Major et al., 1996; Scott et al., 1996a; Umbal, 1997).
Collins and Dunne (1986) documented that in volcanically disturbed landscapes, hillslope erosion rates, which constitute a primary sediment supply to rivers, decrease exponentially as a rill system develops and stabilizes. Downstream sediment yields also depend on the rate of river recovery as the hillslope sediment supply decreases over time after an eruption. The complicating effects of changing sediment supply and the extreme sediment concentrations measured in rivers impacted by volcanic eruptions prevent the application of conventional engineering analyses to predict sediment transport rates and downstream yields following an explosive volcanic eruption (Pearson and Eriksen, 1994). Here we report observations of the magnitude, processes, and effects of fluvial sediment transport and deposition on the Pasig-Potrero River alluvial fan 6 years after the cataclysmic eruption of Mount Pinatubo. Our analysis shows bedload transport in volcanically disturbed rivers reflects higher transport capacities than in their nondisturbed counterparts, and that arid zone channels provide a better analog for predicting post-eruption bedload transport due to their high transport efficiency.

\subsection{The 1991 eruption of Mount Pinatubo and physiographic setting}

Mount Pinatubo is located about $100 \mathrm{~km}$ northwest of Manila on the west coast of the island of Luzon as part of the Luzon volcanic arc (Fig. 2). The volcano consists of steep, deeply dissected upland slopes bounded by coalescing, low-gradient alluvial fans built from products of previous eruptions (Scott et al., 1996a). The mean annual rainfall at Clark Air Base (altitude $146 \mathrm{~m}$ ) is $1950 \mathrm{~mm}$, with $60 \%$ of this falling in July, August, and September (Scott et al., 1996a).

The 1991 eruption of Mount Pinatubo deposited $5-6 \mathrm{~km}^{3}$ of pyroclastic material on the flanks of the volcano, filling adjacent river valleys with up to 200 $\mathrm{m}$ of volcanic debris (Scott et al., 1996b). Within 3 years, rapid river re-incision had transported a third of the volcanogenic sediment downstream (Janda et al., 1996), depositing it on densely populated alluvial fans (Table 1). Initially, most sediment from Mount Pinatubo was transported in lahars, hyperconcentrated to debris flows of volcanic material (Janda et al., 1996). However, as hillslopes stabilized and revegetated and the channel network reestablished, the threshold rain- 


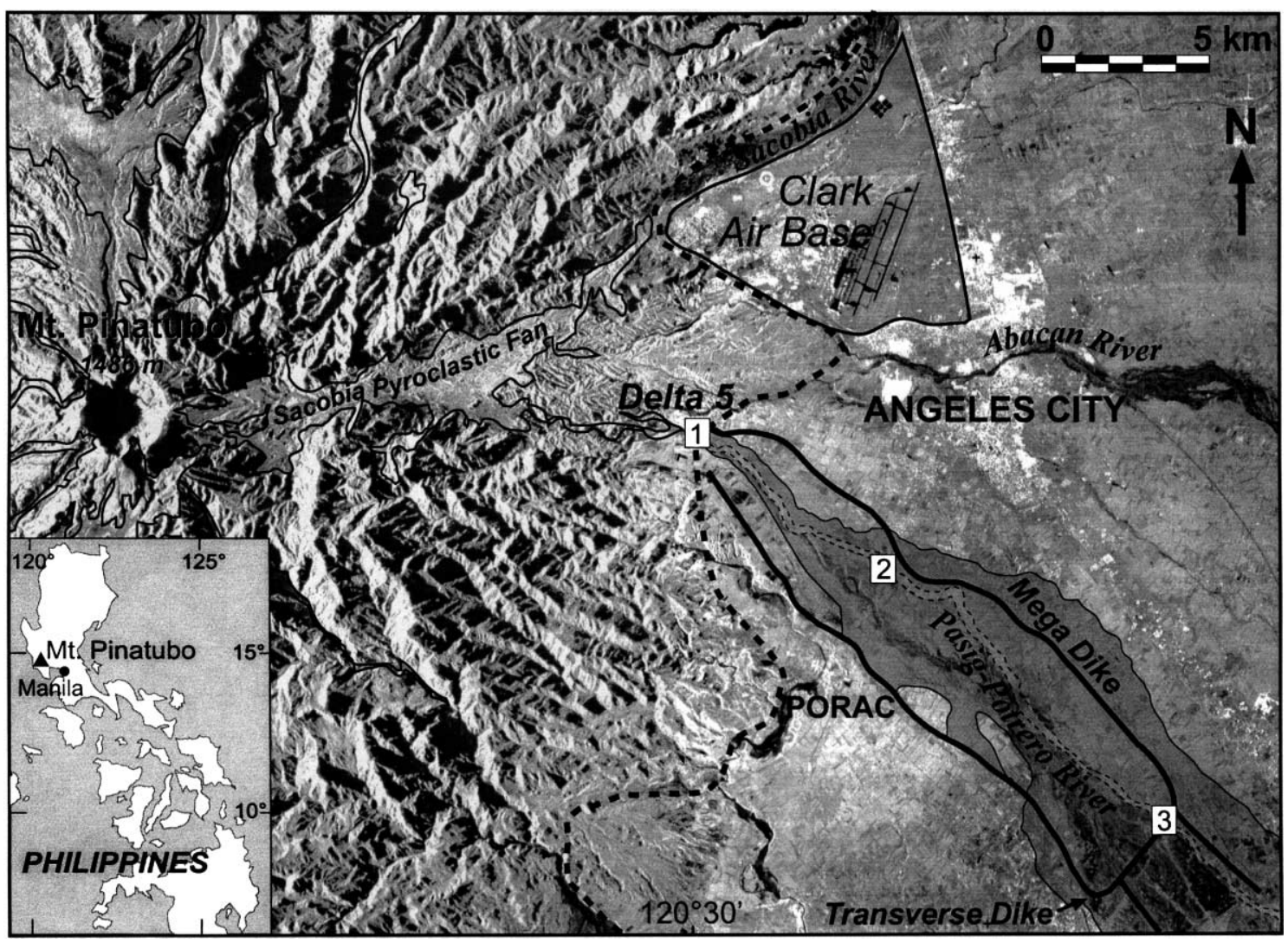

Fig. 2. This 1991 SLAR image (courtesy of Intermap Technologies) of the east side of Mount Pinatubo shows the extent of valley-filling pyroclastic flows (outlined in black) and of lahar deposition along the Pasig-Potrero River through 1997 (shaded dark gray). Sample sites (1) Delta 5, (2) the Angeles-Porac Road, and (3) the Transverse Dike are labeled along the 1997 trace of the Pasig-Potrero River (thin dashed line). A heavy dashed line marks the upper boundary of the coalescing alluvial fans.

fall necessary for lahar initiation increased (Abigania et al., 1998), resulting in an increased proportion of sediment transported by normal river flow.

The Pasig-Potrero River is one of several major rivers draining the east side of Mt. Pinatubo and is one of three rivers, including the Sacobia and Abacan Rivers, draining the Sacobia pyroclastic fan (Fig. 2). In 1991, pyroclastic flows buried 33\% of the PasigPotrero watershed with $0.3 \mathrm{~km}^{3}$ of lithic sand and pumice, filling the valley to an average depth of $50 \mathrm{~m}$ (Major et al., 1996; Scott et al., 1996b). Since the cataclysmic eruption in June 1991, secondary explosions in hot pyroclastic-flow deposits and their associated secondary pyroclastic flows further altered watershed geometry (Umbal, 1997). In October 1993, the Pasig-Potrero River captured a large portion of the Sacobia River watershed, enlarging the
Pasig-Potrero upland from 21 to $44 \mathrm{~km}^{2}$, and greatly increasing the amount of pyroclastic material available for it to transport.

Upon emerging from the upland at a well-defined fanhead, the Pasig-Potrero River flows across a lowgradient alluvial fan composed primarily of older lahar deposits (Fig. 2). On the upper fan, the channel is about $100 \mathrm{~m}$ wide and has incised up to $20 \mathrm{~m}$ into unconsolidated lahar and fluvial deposits below the pre-eruption surface in many places. Down-fan, the channel is wider and less incised.

\subsection{Sediment transport measurements}

We measured sediment transport rates during the 1997 and 1998 rainy seasons at three sites in the PasigPotrero River at and downslope of the alluvial fanhead 
Table 1

Rainfall and lahar deposit volumes for the Pasig-Potrero catchment $1991-1997$

\begin{tabular}{llc}
\hline Year & Annual rainfall ${ }^{\mathrm{a}}(\mathrm{mm})$ & Lahar deposit volume $\left(10^{6} \mathrm{~m}^{3}\right)^{\mathrm{b}}$ \\
\hline 1991 & 2250 & 50 \\
1992 & 2200 & 40 \\
1993 & 2500 & 55 \\
1994 & 2850 & $140^{\mathrm{c}}$ \\
1995 & 2500 & 90 \\
1996 & 2000 & 30 \\
1997 & 1100 & 25 \\
\hline
\end{tabular}

a 1991-1993 data from PI2, MSAC, FNG rain gauges (Janda et al., 1996), 1994-1997 data from upper Sacobia rain gauge (Abigania et al., 1998).

${ }^{\mathrm{b}}$ PHIVOLCS, personal communication, 1998.

c The increase in sediment yield in 1994 reflects stream piracy of the upper Sacobia watershed that almost doubled the PasigPotrero watershed area in October 1993.

(Fig. 2; Table 2). The primary sampling site was Delta 5 lahar watch point, 16 river $\mathrm{km}$ east of the crater at the head of the Pasig-Potrero alluvial/lahar fan. At Delta 5, the Pasig-Potrero is an incised, braided, sand- to gravel-bedded river about $150 \mathrm{~m}$ wide; it has a mean slope of 0.020 determined from a least squares linear regression of a surveyed long profile.

We sampled sediment by the equal-width increment method, which is recommended for sampling shallow streams with an unstable cross-sectional discharge distribution (Edwards and Glysson, 1988), using a US Geological Survey DH-48 sampler with a 1/4-in. $(0.64 \mathrm{~cm})$ nozzle for suspended sediment and a USGS Elwha handheld pressure difference sampler $(20 \times 10$ $\mathrm{cm}$ aperture opening) with a $1-\mathrm{mm}$ mesh bag for bedload. At discharges $>25 \mathrm{~m}^{3} / \mathrm{s}$, sediment sampling was limited to suspended sediment samples taken from or very near the bank. Bedload discharge was calculated assuming $100 \%$ sampler efficiency (D. Childers, USGS, personal communication, 1997). Owing to the spatial and temporal variability of channel morphology observed at the sample reaches, we often sampled bedload in individual braids rather than across the whole channel. We divided each braid into 4 to 15 equally spaced cross-sectional segments and collected samples from the middle of each segment using a 5-s sampling interval. Each set of bedload measurements was repeated four times to minimize error caused by short-term temporal variation, and the sample closest to the average wet mass was used for laboratory analysis. All samples were dried and weighed, and the bedload samples were sieved to remove particles $<1 \mathrm{~mm}$ in diameter, the size of the sampler mesh. Suspended-sediment concentration was determined by filtering the samples and then dividing the weight of the dried sediment by the volume of the total sample. Bedload and suspended-sediment fluxes were then correlated to discharge to produce sediment rating curves.

We estimated discharge by measuring channel width, depth, and surface velocity at the beginning and end of each sampling period. We calculated average surface velocity from the mean travel times of an object floated a known distance along three to four flow paths across the channel, then multiplied the average surface velocity by 0.8 to obtain the average velocity for calculating discharge (Matthes, 1956). Although we realize our velocity estimates are crude, more accurate means of measuring velocity were not available; the high sediment load and large number of rocks rolling in the flow negated use of a cup meter, pressure bulb, or more precise instruments and the substantial amount of magnetite in the sediment prevented use of our sturdier propeller current meter with a magnetic counter. The uncertainty on measurements of channel width $( \pm 1 \mathrm{~m})$, depth $( \pm 0.02 \mathrm{~m})$, and velocity $( \pm 0.1 \mathrm{~m} / \mathrm{s})$ are relatively small; therefore discharge estimates are likely within $15-20 \%$ of the actual discharge. Discharges $>25 \mathrm{~m}^{3} / \mathrm{s}$ were estimated from the channel bank because it was impossible to enter the channel and such measurements are therefore much more uncertain. During these higher flows, we measured flow depth near the channel bank and estimated channel-averaged flow depth visually. We confirmed visual estimates after flow subsided by measuring the diameters of large rocks previously observed rolling in the flow. We calculated surface velocity from floating objects and measured the total incised channel width before and after the peak flow.

\section{Results}

Sediment transport rates in the Pasig-Potrero River remained high during the 1997 and 1998 rainy seasons. Even at very low flow, the water was turbid and opaque and submerged portions of the riverbed were continuous moving carpets of mobile grains. At 
all flow stages, we observed larger grains protruding from the flow, rolling downstream as bedload, and periodic hydraulic bores like those observed in other steep shallow channels with fine-grained, non-cohesive, mobile beds (e.g. Fahnestock, 1963; Foley and Vanoni, 1977; Schumm et al., 1982; Grant, 1997).

At discharges $<25 \mathrm{~m}^{3} / \mathrm{s}$, the river was braided with individual anabranches ranging from shallow, wide channels to deeper, narrow channels with upstreammigrating and stationary standing waves separated by low-amplitude bars (Fig. 3A). During storms, flow tended to rise as individual bores; as flow approached $25 \mathrm{~m}^{3} / \mathrm{s}$, water covered the entire incised channel, and the bed reorganized into channel-wide dunes (Fig. 3B). At these moderate-flow conditions, bank scour was substantial, rocks up to $1 \mathrm{~m}$ in diameter rolled downstream, and bores passed every $20-50 \mathrm{~s}$.

The median grain sizes of the bed surface and subsurface material, determined from pebble counts and bed material samples collected at Delta 5, were 9.8 and $2 \mathrm{~mm}$, respectively. These measurements reflect a fine-grained bed with poorly developed armoring. Fifty-five percent of the bed surface grains $>2 \mathrm{~mm}$ in diameter were sub- to well-rounded pumice particles, with the remaining $45 \%$ being angular fragments of lithic material. Both grain size and the proportion of lithic material on the bed surface decreased down-fan (Table 2).

The channel bed is not only fine-grained but relatively smooth. Roughness values for the three sampled reaches of the Pasig-Potrero River calculated using Manning's equation are similar to values from lowslope, sand-bedded rivers (Simons and Simons, 1987) but are very low relative to other channels with comparable slopes (Fig. 4).

\subsection{Bedload transport}

Measured bedload transport rates in the PasigPotrero River at the head of the alluvial/lahar fan were as high as $93 \mathrm{~kg} / \mathrm{s}$ for discharges less than $11 \mathrm{~m}^{3} / \mathrm{s}$. Total bedload flux $\left(Q_{\mathrm{b}}\right)$ correlated well with discharge, producing a bedload transport rating curve (Fig. 5) with a least squares regression equation of

$Q_{\mathrm{b}}=7.9 Q^{0.88}$

( $n=49, R^{2}=0.82$, standard error of the estimate $=$ 0.18 ). Bedload consisted of a mixture of pumice
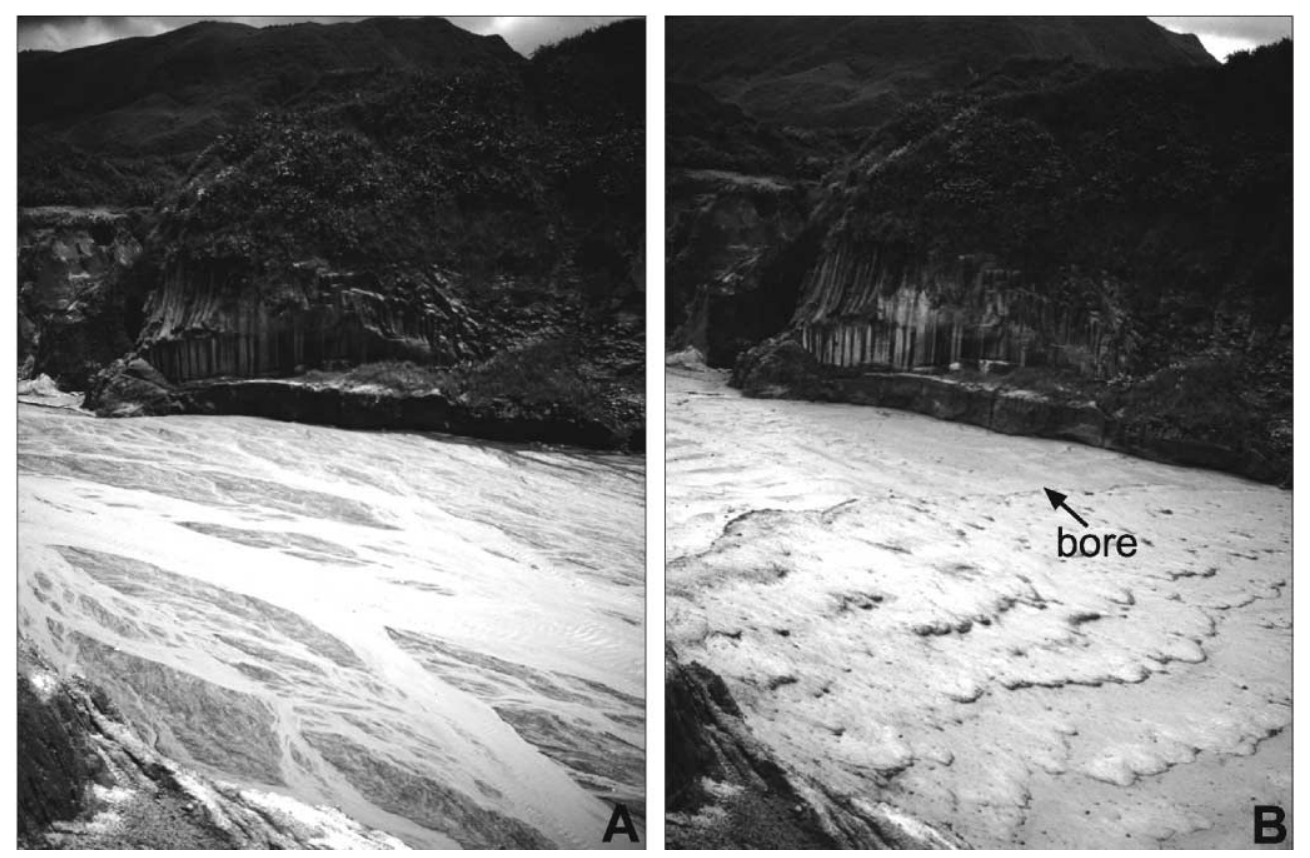

Fig. 3. Flow stages in the Pasig - Potrero River showing bed reorganization from a braided channel (A) to a fully submerged bed with channelwide dunes (B) as flow rises. The channel is about $80 \mathrm{~m}$ wide and flow is from right to left. 
Table 2

Pasig-Potrero alluvial fan sediment sampling sites

\begin{tabular}{lllc}
\hline Sample site & Delta 5 & $\begin{array}{l}\text { Angeles- } \\
\text { Porac Road }\end{array}$ & $\begin{array}{l}\text { Transverse } \\
\text { Dike }\end{array}$ \\
\hline $\begin{array}{l}\text { Distance downstream } \\
\text { from crater (km) }\end{array}$ & 16 & 24 & 36 \\
$\begin{array}{l}\text { Reach average slope } \\
\begin{array}{c}\text { Median bed surface } \\
\text { grain size (mm) }\end{array}\end{array}$ & $\begin{array}{l}0.020 \\
9.8\end{array}$ & $\begin{array}{c}0.009 \\
<2\end{array}$ & $\begin{array}{c}<2 \\
<2\end{array}$ \\
\hline
\end{tabular}

particles with an average saturated density of $1.2 \pm 0.2$ $\mathrm{g} / \mathrm{cm}^{3}$ and lithic fragments with an average saturated density of $2.3 \pm 0.2 \mathrm{~g} / \mathrm{cm}^{3}$. Although many more pumice grains were in transport, lithic grains accounted for a mean $43 \%$ of the weight of particles $>16 \mathrm{~mm}$ in the bedload samples. The grain size of bedload samples in the 50th weight percentile ranged from 2 to $17 \mathrm{~mm}$ with an average of $5 \mathrm{~mm}$. The aperture size of the bedload sampler limited collection to particles less than $10 \times 20 \mathrm{~cm}$, but particles $>10 \mathrm{~cm}$ in diameter covered only $1 \%$ of the bed surface.

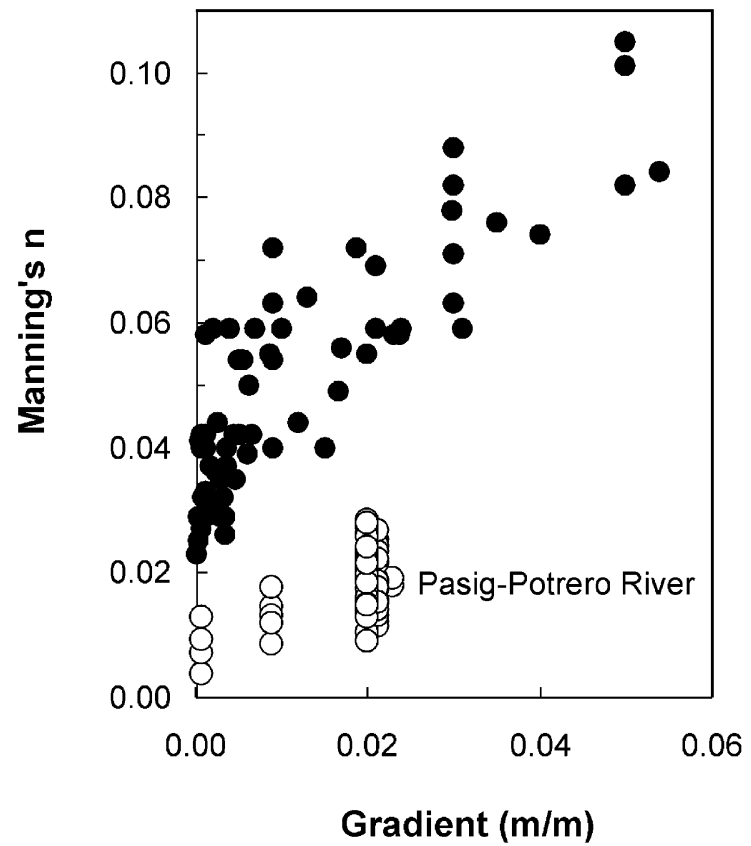

Fig. 4. Relation between Manning's roughness coefficient and slope for the Pasig-Potrero River (open circles) and other mountain drainage basins reported by Barnes (1967) and Marcus et al. (1992) (filled circles). The Pasig-Potrero River data were collected at the study reaches described in Table 1 .

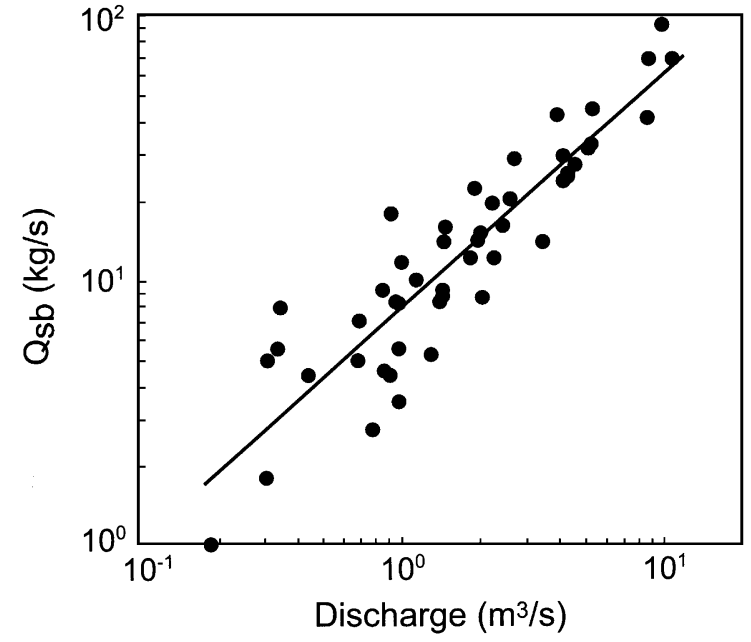

Fig. 5. Bedload discharge rating curve for the Pasig-Potrero River at Delta 5. Data collected during the 1997 and 1998 rainy seasons.

Scatter in the bedload rating curve results from the variability inherent to bedload transport (Gomez, 1991) compounded by active braiding (Davies, 1987), error in estimating discharge, and error in measuring bedload. During the approximately 20 -min sampling periods, braids sometimes widened, filled, or shrank as flow was diverted. The amount of sediment collected by the bedload sampler was probably influenced by local channel changes, such as antidune migration, upstream bank collapse, and the movement of large rocks. Normalization of subgroup standard deviations relative to their respective means for each set of four of channel-wide bedload measurements used to obtain a single bedload data point, indicated an average $20 \%$ variability per sample.

Bedload transport is typically considered to be a function of excess shear stress (Gomez and Church, 1989)

$q_{\mathrm{b}}=\alpha\left(\tau^{\prime}-\tau_{c}\right)^{\beta}$

where $q_{\mathrm{b}}$ is the unit bedload transport rate that occurs when the effective basal shear stress $\left(\tau^{\prime}\right)$ exceeds the critical shear stress required to mobilize the bed $\left(\tau_{\mathrm{c}}\right)$. The effective basal shear stress acting on individual grains $\left(\tau^{\prime}\right)$ is the difference between the total basal shear stress $\left(\tau_{\mathrm{o}}\right)$ (the product of fluid density, gravitational acceleration, average flow depth, and the energy slope) and the shear stress dissipated by other forms of roughness, such as bedforms. Critical shear 
stress $\left(\tau_{\mathrm{c}}\right)$ can be determined from a plot of bedload transport versus total basal shear stress (Fig. 6). Measurements of unit bedload discharge $\left(q_{\mathrm{b}}\right)$ and total basal shear stress $\left(\tau_{\mathrm{o}}\right)$ at Delta 5 are well described by the linear function:

$q_{\mathrm{b}}=0.06 \tau_{0}-0.001$

( $n=49, R^{2}=0.64$, standard error of the estimate $=$ 0.33 ). Setting $q_{\mathrm{b}}$ equal to zero in Eq. (3) indicates a critical shear stress $<0.02 \mathrm{~N} / \mathrm{m}^{2}$, corresponding to a flow depth $<1 \mathrm{~mm}$ for this reach of the Pasig-Potrero River. This small flow depth is not significantly different from zero, implying that there is effectively no minimum threshold discharge for particle motion.

\subsection{Suspended load transport}

We measured suspended sediment concentrations of $9-293 \mathrm{~kg} / \mathrm{m}^{3}$, up to about $20 \%$ by volume, at discharges of $1.2-66 \mathrm{~m}^{3} / \mathrm{s}$ in the Pasig-Potrero River at Delta 5. Suspended-sediment concentration and discharge demonstrated a strong positive correlation but exhibited the typical scatter of concentration versus discharge graphs (Fig. 7). In logarithmic space, the relation between suspended sediment concentra-

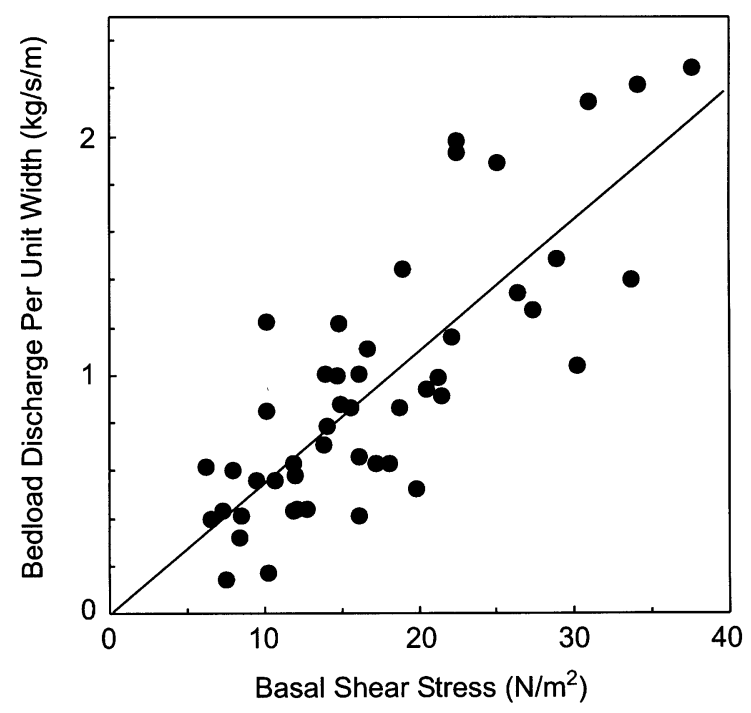

Fig. 6. Bedload flux versus total basal shear stress at Delta 5, 19971998 indicating negligible critical shear stress.

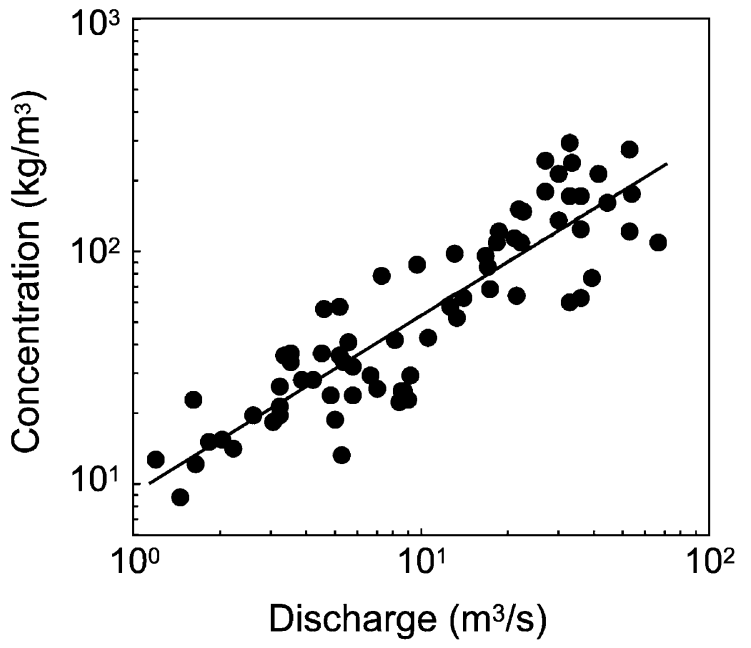

Fig. 7. Suspended sediment concentration versus discharge for the Pasig-Potrero River at Delta 5, 1997-1998.

tion $(C)$ and discharge $(Q)$ can be described by the least squares regression equation

$C=9.5 Q^{0.76}$

based on 71 composite suspended sediment samples $\left(R^{2}=0.78\right.$, standard error of the estimate $\left.=0.18\right)$. The standard deviations of each population of 4 to 10 measurements that composed a single suspended sediment sample averaged $12 \%$. Though discharge only describes $78 \%$ of the variability in suspended sediment concentration, less than that in the bedload rating curve, the low variance within individual samples suggests that the suspended sediment is less subject to sampling error and the scatter seen in Fig. 7 represents the natural variability of sediment supply/transport and error in discharge estimations, particularly in the upper $20 \%$ of the data points at discharges $>25 \mathrm{~m}^{3} / \mathrm{s}$.

\subsection{Sediment deposition and alluvial fan growth}

Two scales of sediment deposition actively shaped the Pasig-Potrero alluvial fan: aggradation of the incised channel bed by fluvial deposition and widespread deposition by lahars. These processes differed in magnitude, duration, and depositional location. During the 1997 and 1998 rainy seasons, fluvial sediment transport and deposition was limited to the incised channel and acted continuously, with most sediment 


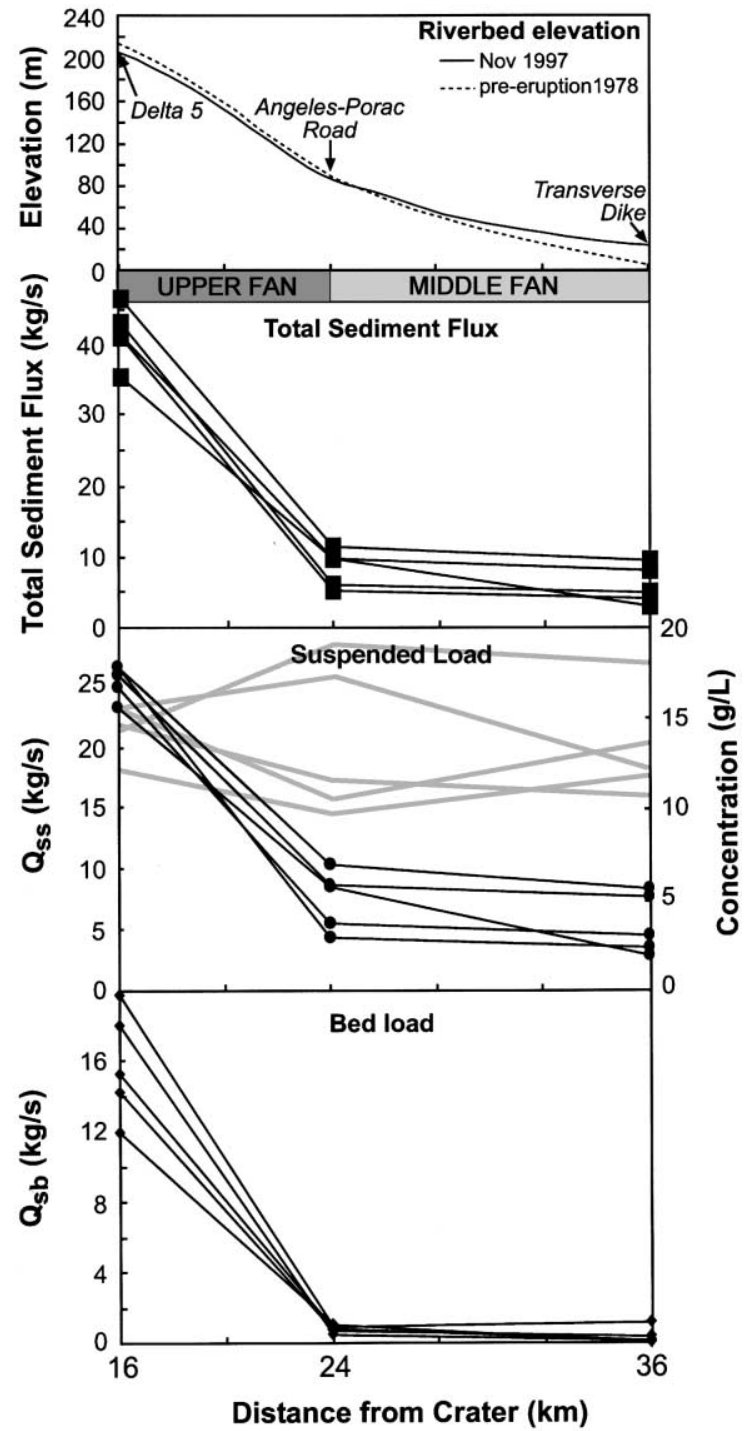

Fig. 8. Spatial analysis of sediment transport rates shows a downfan decrease in transport. Each connected data set (black lines) represents decreasing transport rates measured consecutively downstream at the three locations in a single day. Gray lines representing suspended sediment concentration indicate that there is no down-fan change in suspended sediment concentration. Long profile of the Pasig-Potrero riverbed provided by PHIVOLCS.

transported during small thunderstorms that occurred almost daily. Lahar transport occurred much less frequently, yet accounted for the majority of the total sediment yield of the Pasig-Potrero River (Hayes, 1999).
Measured fluvial sediment transport rates at three locations on the Pasig-Potrero fan 16, 24, and $36 \mathrm{~km}$ from the crater showed a significant decrease in lowflow sediment transport down-fan (Fig. 8). Low-flow transport rates normalized by the amount of sediment transported onto the alluvial/lahar fan past Delta $5(\mathrm{~km}$ 16 ) indicated that $20 \%$ of the total sediment (suspended plus bedload) transported onto the fan remained

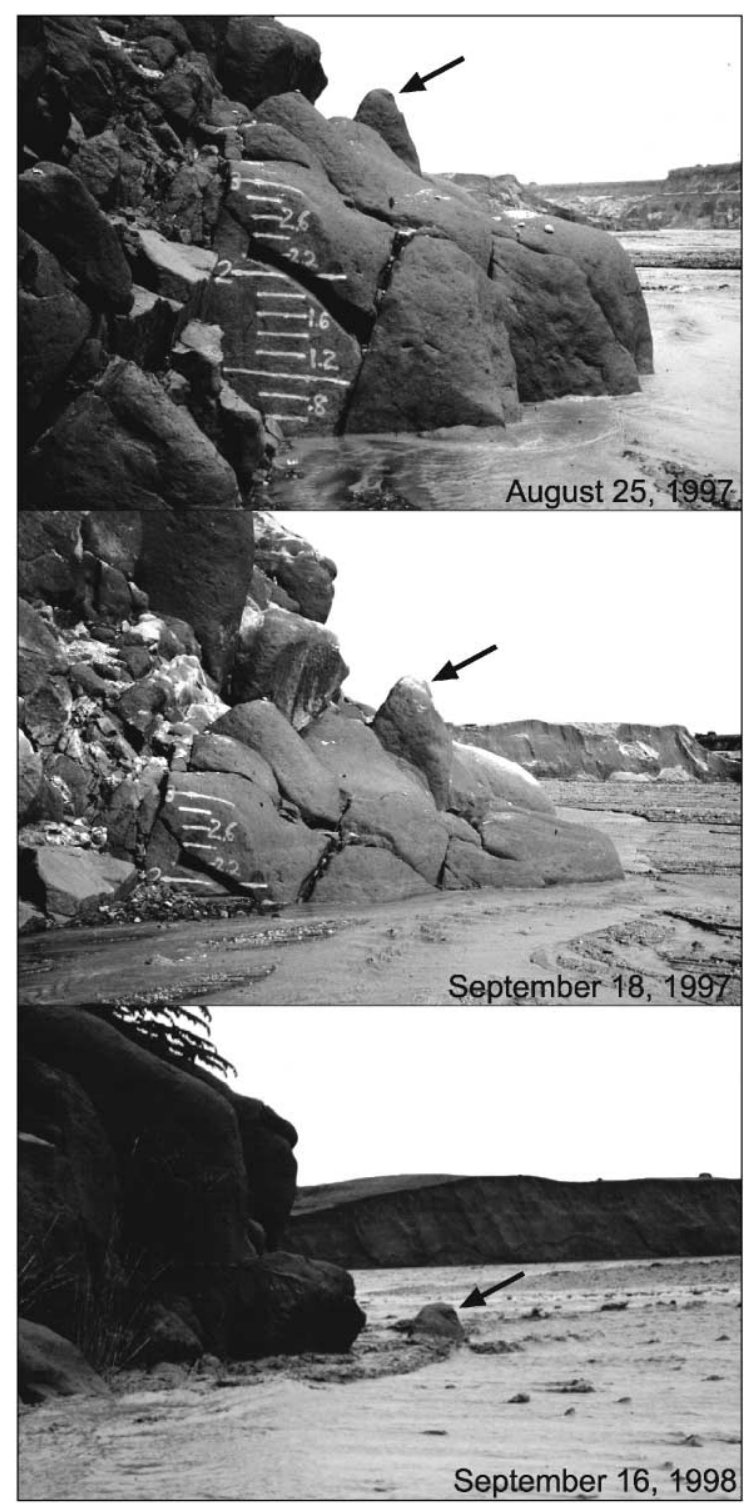

Fig. 9. Time-sequential photographs at Delta 5 illustrating $\sim 5 \mathrm{~m}$ of low-flow bed aggradation from August 1997 to September 1998. 
mobile past $\mathrm{km} 24$, and only $14 \%$ was in motion at the Transverse Dike. The decrease in suspended sediment transport downstream was primarily a function of decreased discharge down-fan due to infiltration of water into the fan and not caused by a systematic decrease in suspended-sediment concentration downfan. Hence, $\sim 80 \%$ of the sediment transported onto the fan by fluvial processes was deposited within the channel on the upper fan.

Measurements of bed aggradation support the conclusion that most fluvially transported sediment was deposited on the upper fan. Bed aggradation documented with a gauge painted on the channel wall at Delta 5 indicated $1.9 \mathrm{~m}$ of low-flow aggradation in 4 weeks in 1997 and $2.2 \mathrm{~m}$ in 5.5 weeks in 1998 (Fig. 9). The net change in channel bed elevation at Delta 5 from August 22, 1997, through September 21, 1998, was $\sim 5 \mathrm{~m}$. No noticeable change in bed elevation occurred at the Transverse Dike either year. The majority of this aggradation occurred during moderate flows $(\sim 30-$ $100 \mathrm{~m}^{3} / \mathrm{s}$ ) caused by small thunderstorms and took place entirely within the incised channel.

Lahar deposition was considerably more variable. Although lahars occur only a few times a year during large storms, they transport and deposit enormous volumes of sediment; overbank lahar deposits blanket a large portion of the mid to lower fan. Lahar depositional zones have migrated up and down the fan resulting in substantial temporal variation in bed elevation at the alluvial fanhead on the order of tens of meters. During the 1997 and 1998 rainy seasons, fluvial sediment transport resulted in bed aggradation at the alluvial fanhead, whereas lahars incised the fanhead and deposited sediment downstream on the middle to lower fan. Stratigraphic evidence from a lahar in August 1997 indicated initial aggradation of the channel bed at Delta 5 of $\sim 4 \mathrm{~m}$, followed by at least $18 \mathrm{~m}$ of erosion, resulting in a net bed elevation loss of $14 \mathrm{~m}$ from the pre-storm channel bed.

\section{Discussion}

\subsection{Similarity between arid and volcanically dis- turbed rivers}

Comparison of dimensionless bedload transport rates to dimensionless shear stress incorporated the effects of different sediment and fluid densities and bed grain size on bedload transport and allowed us to compare transport rates measured in the PasigPotrero River to those of other rivers (Fig. 10). Dimensionless bedload transport rates in the PasigPotrero River were significantly higher than in rivers with more uniform fine-grained beds, e.g. the sandy East Fork River in Wyoming (Emmett et al., 1980, 1985) and coarser, gravel-bedded rivers like Oak Creek in Oregon (Milhous, 1973) for the same shear stress. Yet rates measured in the Pasig-Potrero River were comparable to those measured during flash floods in the ephemeral Nahal Yatir in Israel (Reid et al., 1995) and in the North Fork Toutle River following the 1980 eruption of Mount St. Helens (Pitlick, 1992). The differences in transport rates cannot be explained by simple trends in grain size or slope (Table 3).

The high bedload transport rates measured in the Pasig-Potrero River were due to the combined effects of an enormous supply of easily mobilized, fine-grained sediment and changes in the bed composition and morphology that affected the river's transport efficiency. The massive input of sediment by the 1991 eruption of Mount Pinatubo reduced the bed grain size and overall roughness of the PasigPotrero River by burying the pre-existing channel in the upper watershed under thick deposits of finegrained pyroclastic material (Major et al., 1996). Post-eruption deposition of this sediment produced a wide, flat braidplain devoid of vegetation with a relatively fine-grained, smooth bed with roughness values typical of sand-bedded rivers yet on much steeper slopes than sand-bed channels are typically found.

The eruption supplied far more sediment than the river has been able to transport, thus "swamping" the channel and preventing development of a coarse surface layer (Dietrich et al., 1989; Lisle and Madej, 1992). Recent studies document higher bedload efficiency over smooth beds in arid, ephemeral streams than in channels with coarser-grained surface layers (Laronne and Reid, 1993; Reid and Laronne, 1995) and over sand portions of mixed-bed channels (Ferguson et al., 1989). Furthermore, where gravel and cobbles are transported over a fine-grained bed, the protrusion of large particles into the flow increases the river's competence, or ability to transport larger par- 


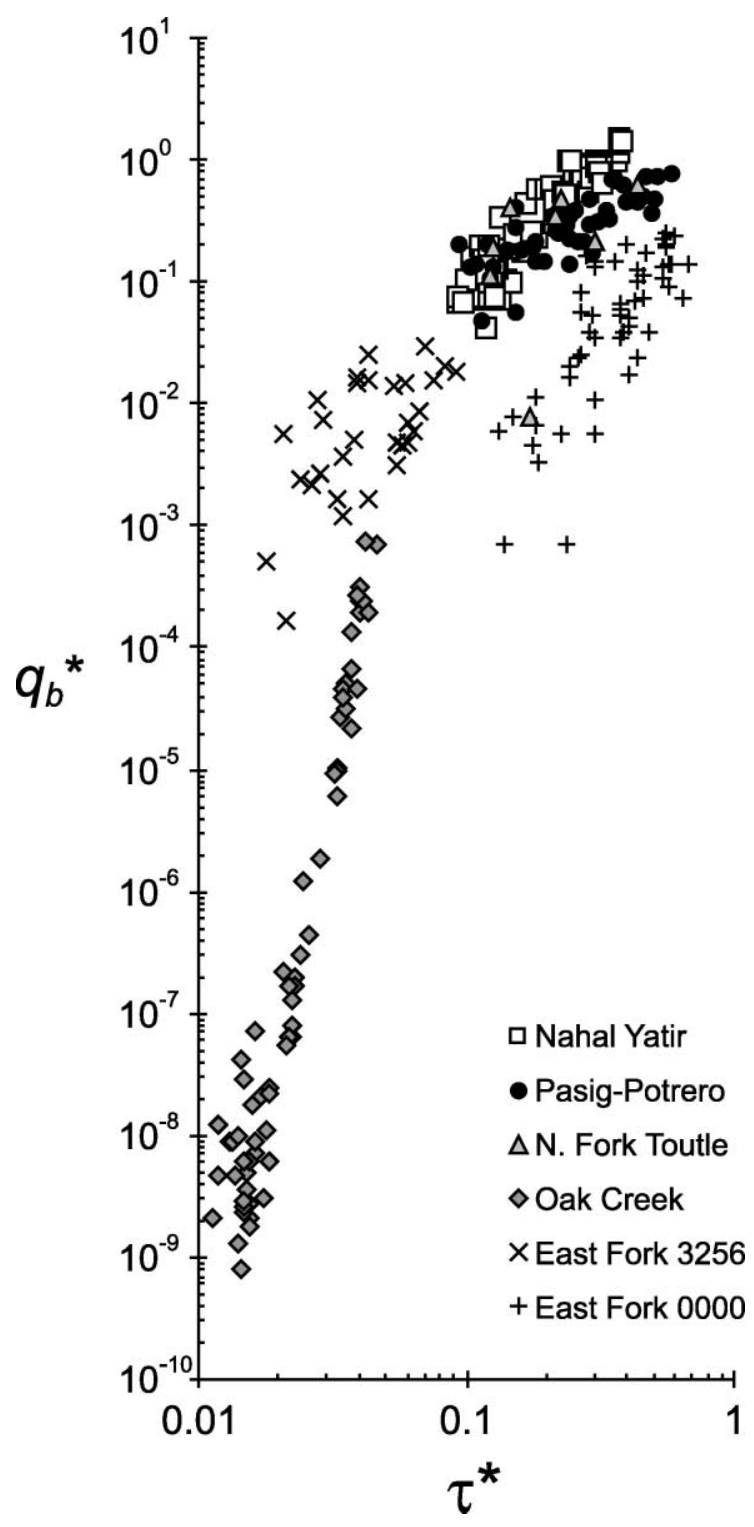

Fig. 10. Comparison of dimensionless bedload transport rates $\left(q_{\mathrm{b}}{ }^{*}\right)$ against dimensionless shear stress $\left(\tau^{*}\right)$ for the Nahar Yatir (Reid et al., 1995), the Pasig-Potrero River, the North Fork Toutle River (Pitlick, 1992), Oak Creek (Milhous, 1973), and two sections on the East Fork River located at the datum and $3256 \mathrm{~m}$ upstream (Emmett et al., 1980, 1985). Dimensionless bedload transport rate $\left(q_{\mathrm{b}}{ }^{*}\right)$ is given by $q_{\mathrm{b}} *=q_{\mathrm{b}} / \rho_{\mathrm{s}}\left[g\left(\rho_{\mathrm{s}}-\rho / \rho\right) D_{50}{ }^{3}\right]^{0.5}$ and dimensionless shear stress $\left(\tau^{*}\right)$ is given by $\tau^{*}=\tau_{0} /\left(\rho_{\mathrm{s}}-\rho\right) g D_{50}$, where $\rho$ and $\rho_{\mathrm{s}}$ are the fluid and sediment densities, $g$ is gravitational acceleration, and $D_{50}$ is the median grain size of the bed surface (Table 3). ticles (Ferguson et al., 1989; Montgomery et al., 1999).

The fine-grained, smooth, steep bed produced by post-eruption deposition of sediment probably also enhanced transport rates by inducing pulsating flow. Pulsating flow, like the periodic bores witnessed in the Pasig-Potrero, is most likely caused by the formation and destruction of antidunes at near-critical flow and is highly erosive due to a temporary increase in flow depth and turbulence (Schumm et al., 1982; Grant, 1997). We observed higher transport rates in the wake of breaking antidunes and during the passage of bores. Large, previously stationary rocks were commonly mobilized and transported short distances by bores.

As bedload transport reflects a balance between the forces acting on the bed and the forces resisting motion (Eq. (2)), a massive disturbance like the 1991 eruption of Mount Pinatubo can alter the bedload transport regime by changing the basal shear stress (via changes in flow conditions) or the critical shear stress (by changing the bed grain size through an increase in sediment supplied to the channel). While hydrologic changes that can affect basal shear stress, such as increased runoff caused by a reduction in infiltration capacity on hillslopes blanketed with finegrained ash, are relatively short-lived, changes to the channel itself can persist for decades flowing a disturbance (Major et al., 2000). In undisturbed systems, channel beds typically reflect flow conditions. However, immediately following a disturbance, channels do not have time to re-adjust to the increased sediment load, resulting in finer-grained beds relative to the pre-disturbance conditions. This in turn causes a temporary increase in excess shear stress and accelerated bedload transport, as seen in channels on Mount Pinatubo and Mount St. Helens. Flash floods in arid environments also tend to have high excess shear stress and therefore high bedload transport rates because the discharges during flash floods are much greater than typical flow conditions (Pitlick, 1992). The high concentrations of suspended sediment measured in the water column at Mount Pinatubo and in flash floods may further enhance bedload transport by increasing the fluid viscosity and density, thus reducing particle settling velocity and increasing basal shear stress (Bradley and McCutcheon, 1987; Simons and Simons, 1987). 
Table 3

Hydraulic and bed characteristics of channels used in bedload transport rate comparison

\begin{tabular}{lllllll}
\hline & $\begin{array}{l}\text { Nahal Yatir, } \\
\text { Israel }\end{array}$ & $\begin{array}{l}\text { Pasig-Potrero, } \\
\text { Mt. Pinatubo }\end{array}$ & $\begin{array}{l}\text { North Fork } \\
\text { Toutle River, } \\
\text { Mt. St. Helens }\end{array}$ & $\begin{array}{l}\text { Oak Creek, } \\
\text { Oregon }\end{array}$ & $\begin{array}{l}\text { East Fork } \\
\text { River 0000 }\end{array}$ & $\begin{array}{l}\text { East Fork } \\
\text { River 3256 }\end{array}$ \\
\hline Sampling method & $\begin{array}{l}\text { Birkbeck- } \\
\text { type slot }\end{array}$ & $\begin{array}{l}\text { Helley-Smith- } \\
\text { type (Elwha) }\end{array}$ & $\begin{array}{l}\text { Helley-Smith- } \\
\text { type (TR-2) }\end{array}$ & $\begin{array}{l}\text { Birkbeck- } \\
\text { type slot }\end{array}$ & $\begin{array}{l}\text { Conveyer- } \\
\text { belt trap }\end{array}$ & $\begin{array}{l}\text { Helley- } \\
\text { Smith }\end{array}$ \\
Average water surface slope & 0.009 & 0.020 & 0.008 & 0.014 & 0.001 & 0.001 \\
Bed surface $D_{50}(\mathrm{~mm})$ & 6 & 9.8 & $\sim 30$ & 60 & 1.4 & 6.8 \\
Subsurface $D_{50}(\mathrm{~mm})$ & 10 & 2 & N.D. & 20 & N.D. & N.D. \\
Bedload $D_{50}(\mathrm{~mm})$ & 6 & 5 & 14 & 48 & 0.68 \\
\hline
\end{tabular}

\subsection{Implications of high post-eruption sediment transport rates}

The observation of very efficient bedload transport has considerable implications for prediction of transport rates following watershed disturbance. Bedload transport equations developed and calibrated in channels with armored beds, such as Oak Creek, or even the same channel prior to an eruption may grossly underestimate post-eruption bedload transport in channels having finer-grained, unarmored beds. Channels in highly disturbed systems undergo morphologic and hydrologic changes that make them more efficient transporting agents, which recover to more stable systems as the sediment supply is reduced. The extreme sediment transport rates observed in the Pasig-Potrero River reflect a positive feedback loop in which the river's transport capacity adjusted to the sediment supply through reduced bed-surface grain size and roughness, which in turn generated faster, shallower, sediment-laden, near-critical flow with high transport efficiency. Higher transport efficiency allowed for removal of more sediment, which helped reduce the overall sediment supply, thus speeding watershed recovery.

Sediment transport following major explosive eruptions can have persistent, far-reaching effects as sediment is carried downstream into populated areas. In 1997, normal streamflow transported $\sim 11$ million $\mathrm{mg}$ of sediment to the Pasig-Potrero alluvial fan, accounting for roughly $25 \%$ of the total annual yield but still two orders of magnitude more than the preeruption sedimentation levels in spite of 1997 being a dry year (JICA, 1978; Hayes, 1999). The high fluvial transport rates documented here lead to substantial deposition on the Pasig-Potrero alluvial/lahar fan- head. Channel bed aggradation reduces conveyance; this loss of channel capacity can enhance the effects of small floods, induce lateral bank erosion and thereby threaten dikes, and increase the potential for channel avulsion during high-flow events. Because recent lahars incised the fanhead while fluvial transport aggraded the channel bed, the sequence of erosion and deposition, in addition to the magnitude of bed aggradation, may be an important factor in determining where and when channel avulsion will occur.

Rivers draining volcanoes are capable of transporting very high sediment loads, similar to loads transported by river in arid climates during flash floods. Yet unlike an arid environment, volcanically disturbed rivers are commonly subject to tropical rainfall. The vast sediment supply and rapid hydrologic response characteristic of an arid environment combined with tropical rainfall is a recipe for extreme sediment yields, such as those experienced at Mount Pinatubo.

\section{Acknowledgements}

We thank Dr. R.S. Punongbayan and the Philippine Institute of Volcanology and Seismology for generous scientific and logistical support. We are grateful to Maria Panfil, Harriet Shields, and Mari Bingham for field assistance and the late Dallas Childers (USGS) for his advice on sediment sampling techniques. Insightful critiques by Gordon Grant, James Knox, W. Andrew Marcus, Jon Major, Jim O'Connor, and an anonymous reviewer greatly improved the manuscript. This research was funded in part by the US Geological Survey/USAID Volcano Disaster Assistance Program. 


\section{References}

Abigania, M.I.T., Arboleda, R.A., Delos Reyes, P.J., Panol, M.D., Tuñgol, N.M., 1998. The Pasig-Potrero River/lahar system: assessment and prognosis for the 1998 rainy season. Philippine Institute of Volcanology and Seismology, internal report.

Barnes, H.H., 1967. Roughness characteristics of natural channels. U.S. Geological Survey Water-Supply Paper 1849, 213 pp.

Bradley, J.B., McCutcheon, S.C., 1987. Influence of large suspended-sediment concentrations in rivers. In: Thorne, C.R., Bathurst, J.C., Hey, R.D. (Eds.), Sediment Transport in Gravel-bed Rivers. Wiley, NY, pp. 645-689.

Chinen, T., Kadomura, H., 1986. Post-eruption sediment budget of a small catchment on Mt. Usu, Hokkaido. Zeitschrift fuer Geomorphologie, Supplementband 60, 217-232.

Collins, B.D., Dunne, T., 1986. Erosion of tephra from the 1980 eruption of Mount St. Helens. Geological Society of America Bulletin 97 (7), 905-986.

Cronin, S., Neall, V., Lecointre, J., Palmer, A., 1999. Dynamic interactions between lahars and stream flow; a case study from Ruepehu Volcano, New Zealand. Geological Society of America Bulletin 111 (1), 28-38.

Davies, T.R.H., 1987. Problems of bedload transport in braided gravel-bed rivers. In: Thorne, C.R., Bathurst, J.C., Hey, R.D. (Eds.), Sediment Transport in Gravel-bed Rivers. Wiley, NY, pp. $793-841$.

Dietrich, W.E., Kirchner, J.W., Ikeda, H., Iseya, F., 1989. Sediment supply and the development of the coarse surface layer in gravel-bedded rivers. Nature 340 (6230), 215-217.

Dinehart, R.L., 1998. Sediment transport at gauging stations near Mount St. Helens, Washington, 1980-90. Data collection and analysis. U.S. Geological Survey Professional Paper 1573, 105 pp.

Edwards, T.K., Glysson, G.D., 1988. Field methods for measurement of fluvial sediment. U.S. Geological Survey Open-File Report 86-531, 118 pp.

Emmett, W.W., Myrick, R.M., Meade, R.H., 1980. Field data describing the movement and storage of sediment in the East Fork River, Wyoming: Part I. River hydraulics and sediment transport, 1979. U.S. Geological Survey Open-File Report 80-1189, 43 pp.

Emmett, W.W., Myrick, R.M., Martinson, H.A., 1985. Hydraulic and sediment-transport data, East Fork River, Wyoming, 1978. U.S. Geological Survey Open-File Report 85-486, 37 pp.

Fahnestock, R.K., 1963. Morphology and hydrology of a glacial stream-white river, Mount Rainier, Washington. U.S. Geological Survey Professional Paper 422 A, 69 pp.

Ferguson, R.I., Prestegaard, K.L., Ashworth, P.J., 1989. Influence of sand on hydraulics and gravel transport in a braided gravel bed river. Water Resources Research 25 (4), 635-643.

Foley, M.G., Vanoni, V.A., 1977. Pulsing flow in steep alluvial streams. Journal of the Hydraulics Division, American Society of Civil Engineers 103 (2), 843-850.

Gomez, B., 1991. Bedload transport. Earth-Science Reviews 31 (2), $89-132$

Gomez, B., Church, M., 1989. An assessment of bedload sediment transport formulae for gravel bed rivers. Water Resources Research $25(6), 1161-1186$.
Grant, G.E., 1997. Critical flow constrains flow hydraulics in mobile-bed streams: a new hypothesis. Water Resources Research 33 (2), 349-358.

Hamidi, S., 1989. Lahar of Galunggung Volcano from 1982 through 1986. Proceedings of International Symposium on Erosion and Volcanic Debris Flow Technology, July 31 -August 3. Ministry of Public Works, Yogyakarta, Indonesia, pp. V1-1-VP1-23.

Hayes, S.K., 1999. Low-flow sediment transport on the Pasig-Potrero alluvial fan, Mount Pinatubo, Philippines. MS Thesis, University of Washington, Seattle.

Hirao, K., Yoshida, M., 1989. Sediment yield of Mt. Galunggung after eruption in 1982. Proceedings of International Symposium on Erosion and Volcanic Debris Flow Technology, July $31-$ August 3. Ministry of Public Works, Yogyakarta, Indonesia, pp. V21-1-V21-22.

Hodgson, K., Manville, V., 1999. Sedimentology and flow behavior of a rain-triggered lahar, Mangatoetoenui Stream, Ruapehu Volcano, New Zealand. Geological Society of America Bulletin 111 (5), $743-754$.

Inbar, M., Lugo Hubp, J., Villers Ruiz, L., 1994. The geomorphological evolution of the Paricutin cone and lava flows, Mexico, 1943 - 1990. Geomorphology 9 (1), 57-76.

Janda, R.J., Meyer, D.F., Childers, D., 1984a. Sedimentation and geomorphic changes during and following the 1980-1983 eruptions of Mount St. Helens, Washington, I. Shin-Sabo Journal of the Erosion Control Engineering Society of Japan 37 (2), $10-$ 21.

Janda, R.J., Meyer, D.F., Childers, D., 1984b. Sedimentation and geomorphic changes during and following the 1980-1983 eruptions of Mount St. Helens, Washington, II. Shin-Sabo Journal of the Erosion Control Engineering Society of Japan 37 (3), 5-19.

Janda, R.J., Daag, A.S., Delos Reyes, P.J., Newhall, C.G., Pierson, T.C., Punongbayan, R.S., Rodolfo, K.S., Solidum, R.U., Umbal, J.V., 1996. Assessment and response to lahar hazard around Mount Pinatubo, 1991 to 1993. In: Newhall, C.G., Punongbayan, R.S. (Eds.), Fire and Mud, Eruptions and Lahars of Mount Pinatubo, Philippines. PHIVOLCS Press, Quezon City, and University of Washington Press, Seattle, pp. 107-139.

Japan International Cooperating Agengy (JICA), 1978. Planning Report on the Pasig-Potrero River Flood Control and Sabo Project: JICA, Tokyo, Japan.

Kadomura, H., Imagawa, T., Hiroshi, Y., 1983. Eruption-induced rapid erosion and mass movements on Usu Volcano, Hokkaido. Zeitschrift fuer Geomorphologie, Supplementband 46, 124-142.

Laronne, J., Reid, I., 1993. Very high rates of bedload sediment transport by ephemeral desert rivers. Nature 366 (6451), $148-$ 150.

Leavesley, G.H., Lusby, G.C., Lichty, R.W., 1989. Infiltration and erosion characteristics of selected tephra deposits from the 1980 eruption of Mount St. Helens, Washington, USA. Hydrological Sciences 34 (3), 339-353.

Lisle, T.E., Madej, M.A., 1992. Spatial variation in armouring in a channel with high sediment supply. In: Billi, P., Hey, R.D., Thorne, C.R., Tacconi, P. (Eds.), Dynamics of Gravel-bed Rivers. Wiley, NY, pp. 277-293.

Lisle, T.E., Lehre, A.K., Martinson, H.A., Meyer, D.F., Nolan, K.M., Smith, R.D., 1983. Stream channel adjustments after 
the 1980 Mount St. Helens eruptions. Symposium on Erosion Control in Volcanic Areas, Proceedings. Technical Memorandum of Public Works Research Institute, vol. 1908. Ministry of Construction, Japan, pp. 33-72.

Major, J.J., Janda, R.J., Daag, A.S., 1996. Watershed disturbance and lahars on the east side of Mount Pinatubo during the midJune 1991 eruptions. In: Newhall, C.G., Punongbayan, R.S. (Eds.), Fire and Mud, Eruptions and Lahars of Mount Pinatubo, Philippines. PHIVOLCS Press, Quezon City, and University of Washington Press, Seattle, pp. 895-920.

Major, J.J., Pierson, T.C., Dinehart, R.L., Costa, J.E., 2000. Sediment yield following severe volcanic disturbance- a two-decade perspective from Mount St. Helens. Geology 28 (9), 819-822.

Marcus, W.A., Roberts, K., Harvey, L., Tackman, G., 1992. An evaluation of methods for estimating Manning's $n$ in small mountain streams. Mountain Research and Development 12, 227-239.

Matthes, G., 1956. River surveys in unmapped territory. American Society of Civil Engineers, Transactions 121, 739-758.

Meyer, D.F., Martinson, H.A., 1989. Rates and processes of channel development and recovery following the 1980 eruption of Mount St. Helens, Washington. Hydrological Sciences 34 (2), 115-127.

Milhous, R.T., 1973. Sediment transport in a gravel-bottomed stream. PhD Dissertation, Oregon State University, Corvallis.

Milliman, J.D., Syvitski, J.P.M., 1992. Geomorphic/tectonic control of sediment discharge to the ocean: the importance of small mountainous rivers. Journal of Geology 100 (5), 525-544.

Mizuyama, T., Kobashi, S., 1996. Sediment yield and topographic change after major volcanic activity. Erosion and Sediment Yield: Global and Regional Perspectives, vol. 236. IAHS Publication, Wallingford, Oxfordshire, pp. 259-301.

Montgomery, D.R., Panfil, M.S., Hayes, S.K., 1999. Channel-bed mobility response to extreme sediment loading at Mount Pinatubo. Geology 27 (3), 271-274.

Ollier, C.D., Brown, M.J.F., 1971. Erosion of a young volcano in New Guinea. Zeitschrift fuer Geomorphologie 15 (1), 12-28.

Pearson, M.L., Eriksen, K.W., 1994. Geomorphic and sedimentation investigation of the 15 June 1991 eruption of Mount Pinatubo, the Philippines. Technical report U.S. Army Engineer Waterways Experiment Station GL-94-14, 106 pp.

Pierson, T.C., Janda, R.J., Umbal, J.V., Daag, A.S., 1992. Immediate and long-term hazards from lahars and excess sedimentation in rivers draining Mt. Pinatubo, Philippines. U.S. Geological Survey Water-Resources Investigations Report 92-4039, 35 pp.

Pierson, T.C., Daag, A.S., Delos Reyes, P.J., Regalado, M.T.M., Solidum, R.U., Tubianosa, B.S., 1996. Flow and deposition of posteruption hot lahars on the east side of Mount Pinatubo, July-October 1991. In: Newhall, C.G., Punongbayan, R.S. (Eds.), Fire and Mud, Eruptions and Lahars of Mount Pinatubo, Philippines. PHIVOLCS Press, Quezon City, and University of Washington Press, Seattle, pp. 921-950.

Pitlick, J., 1992. Flow resistance under conditions of intense gravel transport. Water Resources Research 28 (3), 891-903.

Reid, I., Laronne, J., 1995. Bedload sediment transport in an ephemeral stream and a comparison with seasonal and perennial counterparts. Water Resources Research 31 (3), 773-781.
Reid, I., Laronne, J., Powell, D., 1995. The Nahal Yatir bedload database: sediment dynamics in a gravel-bed ephemeral stream. Earth Surface Processes and Landforms 20 (9), 845-857.

Rodolfo, K.S., 1989. Origin and early evolution of lahar channel at Mabinit, Mayon Volcano, Philippines. Geological Society of America Bulletin 101 (3), 414-426.

Rodolfo, K.S., Arguden, A.T., 1991. Rain-lahar generation and sediment-delivery systems at Mayon Volcano, Philippines. In: Fisher, R.V., Smith, G.A. (Eds.), Sedimentation in Volcanic Settings. SEPM Special Publication, vol. 45, pp. 71-87. Tulsa, OK.

Schumm, S.A., Bean, D.W., Harvey, M.D., 1982. Bed-form-dependant pulsating flow in Medano Creek, Southern Colorado. Earth Surface Processes and Landforms 7 (1), 17-28.

Scott, K.M., Janda, R.J., de la Cruz, E.G., Gabinete, E., Eto, I., Isada, M., Sexton, M., Hadley, K.C., 1996. Channel and sedimentation responses to large volumes of 1991 volcanic deposits on the east flank of Mount Pinatubo. In: Newhall, C.G., Punongbayan, R.S. (Eds.), Fire and Mud, Eruptions and Lahars of Mount Pinatubo, Philippines. PHIVOLCS Press, Quezon City, and University of Washington Press, Seattle, pp. 971-988.

Scott, W.E., Hoblitt, R.P., Torres, R.C., Self, S., Martinez, M.M.L., Nillos, T., 1996. Pyroclastic flows of the June 15, 1991, climactic eruption of Mount Pinatubo. In: Newhall, C.G., Punongbayan, R.S. (Eds.), Fire and Mud, Eruptions and Lahars of Mount Pinatubo, Philippines. PHIVOLCS Press, Quezon City, and University of Washington Press, Seattle, pp. 545-570.

Segerstrom, K., 1950. Erosion studies at Parícutin, State of Michoacán, Mexico. U.S. Geological Survey Bulletin 965-A, 1-64.

Segerstrom, K., 1960. Erosion and related phenomena at Parícutin in 1957. U.S. Geological Survey Bulletin 1104-A, 1-18.

Segerstrom, K., 1966. Parícutin, 1965-aftermath of eruption. U.S. Geological Survey Professional Paper 550-C, C93-C101.

Shimokawa, E., Taniguchi, Y., 1983. Sediment yield from hillslopes on active volcanoes. Symposium on Erosion Control in Volcanic Areas, Seattle and Vancouver, WA, July 6-9, 1982, Proceedings, 155-182 Technical Memorandum of Public Works Research Institute, Ministry of Construction, Japan.

Simon, A., 1999. Channel and drainage-basin response of the Toutle River system in the aftermath of the 1980 eruption of Mount St. Helens, Washington. U.S. Geological Survey Open-File Report 96-633, 130 pp.

Simons, D.B., Simons, R.K., 1987. Differences between gravel- and sand-bed rivers. In: Thorne, C.R., Bathurst, J.C., Hey, R.D. (Eds.), Sediment Transport in Gravel-bed Rivers. Wiley, NY, pp. 3-15.

Smith, G.A., Lowe, D.R., 1991. Lahars: volcano-hydrologic events and deposition in the debris flow-hyperconcentrated flow continuum. In: Fisher, R.V., Smith, G.A. (Eds.), Sedimentation in Volcanic Settings. SEPM Special Publication, vol. 45, pp. $60-$ 70. Tulsa, OK.

Swanson, F.J., Collins, B., Dunne, T., Wicherski, B.P., 1983. Erosion of tephra from hillslopes near Mt. St. Helens and other volcanoes. Proceedings of the Symposium on Erosion Control in Volcanic AreasTechnical Memorandum of the Public Works Research Institute, vol. 1908. Ministry of Construction, Japan, pp. $183-221$. 
Umbal, J.V., 1997. Five years of lahars at Pinatubo volcano: declining but still potentially lethal hazards. Journal of the Geological Society of the Philippines 52, 1-19.

Waldron, H., 1967. Debris flow and erosion control problems caused by the ash eruptions of Irazú Volcano, Costa Rica. U.S. Geological Survey Bulletin 1241-I, 37 pp.
Watanabe, M., Ikeya, H., 1981. Investigations and analysis of volcanic mud flows on Mt. Sakurajima, Japan. Erosion and Sediment Transport Measurement, vol. 113. IAHS Publication, Wallingford, Oxfordshire, U.K., pp. 245-256. 